\title{
Cryptic species of the genus Pimelodella (Siluriformes: Heptapteridae) from the Miranda River, Paraguay River basin, Pantanal of Mato Grosso do Sul, Central Brazil
}

\author{
Lenice Souza-Shibatta ${ }^{1}$, Larissa Forim Pezenti ${ }^{2}$, Dhiego Gomes Ferreira ${ }^{3}$, Fernanda \\ Simões de Almeida ${ }^{2,4}$, Silvia Helena Sofia ${ }^{1,3,4}$ and Oscar Akio Shibatta ${ }^{1}$
}

Specimens of Pimelodella captured in the Miranda River, Pantanal of Mato Grosso do Sul State, present morphological features that could indicate at least four species. Therefore, karyotype analysis and molecular biology provided evidence that they were only two species, one showing $2 n=46$, and the other, $2 n=52$ chromosomes, with only $18 \%$ genetic similarity. The morphological analysis evidenced that the dorsal filament is a male characteristic and that the upper lobe of the caudal fin was variable and might or might not be elongated in both species. With respect to morphometric characters, the formation of two groups was evident, but with a small overlap of specimens between them. Among the species with filaments on the dorsal fin observed in the Pantanal, the one with the lesser length of adipose fin base is $P$. griffini, which corresponds to that with $2 \mathrm{n}=$ 46 chromosomes, whereas the species $P$. taenioptera has $2 \mathrm{n}=52$ chromosomes. Thus, the accurate detection of these cryptic taxonomic units was only possible with the use of various analysis techniques. Furthermore, it is worth noting that the identification of cryptic species is important for obtaining correct estimates of fish diversity in the Pantanal.

Exemplares de Pimelodella capturados no rio Miranda, Pantanal do Mato Grosso do Sul, apresentavam características morfológicas que poderiam indicar, pelo menos, quatro espécies. Entretanto, com a análise cariotípica e da biologia molecular ficou evidente que se tratava de apenas duas espécies, uma apresentando $2 \mathrm{n}=46$ e a outra, $2 \mathrm{n}=52$ cromossomos, e com apenas $18 \%$ de similaridade genética. Pela análise morfológica foi observado que o filamento dorsal é uma característica de machos, e o lobo superior da nadadeira caudal se mostrou variável, podendo, ou não, ser alongado em ambas espécies. Com relação aos caracteres morfométricos, também houve a formação de dois grupos, mas com uma pequena sobreposição de exemplares entre eles. Das espécies com filamento na nadadeira dorsal apontadas para o Pantanal, a que possui menor comprimento da base da nadadeira adiposa é $P$. griffini, o que corresponde àquela com $2 \mathrm{n}=46$ cromossomos e, ao contrário, a espécie com $2 \mathrm{n}=52$ cromossomos, é $P$. taenioptera. Assim, apenas com o emprego de diversas técnicas de análise foi possível o reconhecimento seguro dessas unidades taxonômicas que se mostravam crípticas. Ressalta-se, ainda, que a identificação de espécies crípticas é importante para que estimativas da diversidade de peixes do Pantanal sejam feitas corretamente.

Key words: Cytotaxonomy, Cytogenetics, Multivariate morphometrics, RAPD.

\section{Introduction}

The Neotropical region harbors the most representative groups of freshwater fish in the world, with about 6,000 of the 13,000 existing species (Reis et al., 2003). This region is a vast sedimentary wetland plain called Pantanal, which has a very rich fish fauna, with approximately 260 identified species, including small and medium-sized catfish, such as Heptapteridae (Britski et al., 2007). Currently, this is the most diverse family within the order Siluriformes, and Pimelodella Eigenmann \& Eigenmann, 1888 is their most specious genus, with 71 valid species (Bockmann \& Guazzelli, 2003).

\footnotetext{
${ }^{1}$ Universidade Estadual de Londrina, Programa de Pós-Graduação em Ciências Biológicas, Departamento de Biologia Animal e Vegetal, Centro de Ciências Biológicas, 86051-990 Londrina, PR, Brazil. lenicesouza@hotmail.com (LSS); shibatta@uel.br(OAS).

${ }^{2}$ Universidade Estadual de Londrina, Especialização em Genética, Departamento de Biologia Geral, Centro de Ciências Biológicas, 86051990 Londrina, PR, Brazil.

${ }^{3}$ Universidade Estadual de Londrina, Programa de Pós-Graduação em Genética e Biologia Molecular, Departamento de Biologia Geral, Centro de Ciências Biológicas, 86051-990 Londrina, PR, Brazil.

${ }^{4}$ Universidade Estadual de Londrina, Departamento de Biologia Geral, Centro de Ciências Biológicas, 86051-990 Londrina, PR, Brazil.
} 
Six species of Pimelodella have been observed in the Pantanal (Britski et al., 2007) and are traditionally differentiated by the presence of elongate filaments on the dorsal fin ( $v s$. absence); elongate upper lobe of caudal fin ( $v s$. same length as the lower); color (dark spot on dorsal fin; dark stripe along the body); and the presence of hypertrophied lateral line pores on the ventral region of the head. Specimens of Pimelodella captured in the Miranda River, Pantanal of Mato Grosso do Sul State, exhibited morphological features that could involve at least four species (Pimelodella gracilis Valenciennes, 1835, P. megalura Miranda-Ribera, 1918, P. taenioptera MirandaRibeiro, 1914, and P. griffini Eigenmann, 1917), since some specimens did or did not present an elongate filament on the dorsal fin, as well as an upper lobe of the caudal fin elongated or with the length similar to that of the lower lobe.

Thence, the objective of this study was to analyze these specimens in the light of cytogenetics, molecular biology, and morphology, to test the hypothesis that they might belong to those four species.

\section{Material and Methods}

The specimens of Pimelodella, subject of this study, were collected from the left bank of the Miranda River, at Base de Estudos do Pantanal (BEP), belonging to the Universidade Federal do Mato Grosso do Sul (BEP/UFMS), Municipality of Corumbá, Mato Grosso do Sul, in the region known as Passo

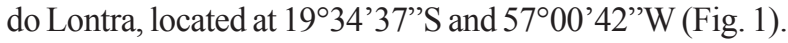

The specimens were collected by trawl with a mesh of $2 \mathrm{~mm}$ between the adjacent knots or fished with rod and hook, and kept alive in a tank with dechlorinated tap water at a temperature of $25^{\circ} \mathrm{C}$. For the analyses, the specimens were later killed by overexposure to the anesthetic $(1.0 \mathrm{~mL}$ of $5 \%$ benzocaine for each liter of water).

The species were identified according to Miranda-Ribeiro (1914), Eigenmann (1917) and Britski et al. (2007). The specimens are deposited in the Museu de Zoologia da

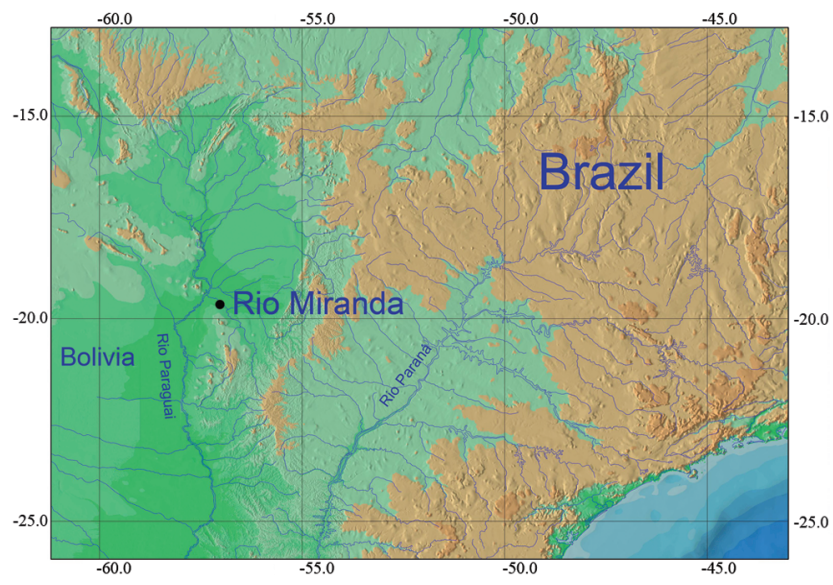

Fig. 1. Collection sites of Pimelodella specimens (black circle, $19^{\circ} 34^{\prime} 37^{\prime \prime} \mathrm{S}$ and $57^{\circ} 00^{\prime} 42^{\prime \prime} \mathrm{W}$ ) in the Miranda River basin, Passo do Lontra, Mato Grosso do Sul State, Brazil.
Universidade Estadual de Londrina (MZUEL), Paraná, Brazil (MZUEL 6455 to 6460).

Mitotic chromosomes were obtained through the technique described by Bertollo et al. (1978) and classified according to the methodology proposed by Levan et al. (1964). As it is possible that different species share the same diploid number, especially if they belong to the same genus, as observed by Souza et al. (2004), molecular analyses were performed to verify whether those chromosome numbers actually represented only one particular species.

For the molecular analyses, samples were removed from muscle tissue and placed in $2 \mathrm{~mL}$ cryopreservation tubes with absolute ethanol and stored in a freezer at $-20^{\circ} \mathrm{C}$. The specimens were then fixed in $10 \%$ formalin and preserved in $70 \%$ alcohol. The extraction and quantification of genomic DNA were based on Almeida et al. (2003), and for the obtainment of genetic identity, we used the PCR-RAPD (Random Amplified Polymorphic DNA) technique. Thirty different primers (OPA, OPAC, OPC, OPM and OPX Kits from Operon Technologies Ltd.) were tested for the analysis and those presenting the best electrophoretic profile and distinct banding pattern were selected. To assess the level of reliability of the results, the coefficient of variation for the number of amplified markers (CV\%) was calculated using the program dBoot v. 1.1 (Coelho, 2001). For the analysis of genetic similarity, we used the computer program NTSYS-PC (Rohlf, 2000), employing the Jaccard coefficient (J) and the UPGMA clustering method.

The body measurements were taken point to point with the aid of digital calipers with $0.01 \mathrm{~mm}$ accuracy, following the protocol developed by Shibatta (1998). The following measurements were taken: standard length, head length, snout length, eye diameter, pre-dorsal distance, length of dorsal fin base, length of adipose-fin base, dorsal fin spine length, caudal peduncle height, pre-ventral distance, length of anal fin base, length of pectoral fin spine, and interorbital distance. The measurements, except those for the barbel length, formed a matrix that was analyzed with the employment of multivariate statistics of the Principal Components with axis distortion, known as Shear, following the protocol of Bookstein et al. (1985). The statistical package utilized for this analysis is called Shear (Mcleod, 1990), and the interpretations of the axes were accomplished according to Neff \& Marcus (1981). The body proportions of the measurements relative to head were calculated in relation to the lengths of the head and body, and the lengths of the head and barbel were estimated in relation to the standard length. The differences in body proportions among species were analyzed applying the $t$ Student test using the statistical package PAST (Hammer et al. 2001). We also calculated the allometric coefficient for the upper lobe of the caudal fin in relation to standard length applying the least-squares method, where the angular coefficient (b) with a value higher than 1 was considered positive allometric; lower than 1 , negative allometric; and equal to 1 , isometric. The assessment of pectoral-fin spines of the two species was made in relation to the size of the anterior 
and posterior saw-toothed margins, and compared with the illustrations presented by Eigenmann (1917). One sample of each species was cleared and stained in accordance with Dingerkus \& Uhler (1977) to facilitate the visualization of spines details. The presence of the elongate filament on the second dorsal-fin ray (which forms the spines) was related to the chromosomal number and sex.

\section{Results}

Cytogenetics. We analyzed 33 specimens, considering an average of 30 metaphases per individual. Of these, 15 specimens presented $2 \mathrm{n}=46$ chromosomes and 18 specimens, $2 \mathrm{n}=52$ chromosomes (Figs. 2a-b), indicating that the sample comprised two species. The species with $2 \mathrm{n}$ $=46$ chromosomes showed 19 pairs of meta/submetacentric chromosomes and four pairs of subtelo/acrocentric chromosomes, with a secondary constriction on the second pair of meta/submetacentric chromosomes. The species with
$2 \mathrm{n}=52$ chromosomes presented 21 pairs of meta/ submetacentric chromosomes and five pairs of subtelo/ acrocentric chromosomes, and did not present sex heteromorphism. We did not observe any supernumerary chromosomes in both species.

Molecular Biology. We selected nine primers (OPA2, OPAC 4, APAC 7, OPC 2, OPM 13, OPM 20, OPX OPX 6 and 12) that resulted in 181 loci. These proved to be sufficient for the analysis, due to the value of the coefficient of variation (CV), which stabilized around 5\%, indicating a high level of reliability.

The comparative analysis of 18 specimens, 11 with $2 \mathrm{n}=$ 52 and 7 with $2 n=46$, revealed the presence of two different RAPD profiles in all primers utilized, which had a close relationship with the two chromosomal groups. The dendrogram (Fig. 3) revealed that the similarity between the two groups was only $18 \%$, clearly indicating the presence of two species and corroborating the cytogenetic data.
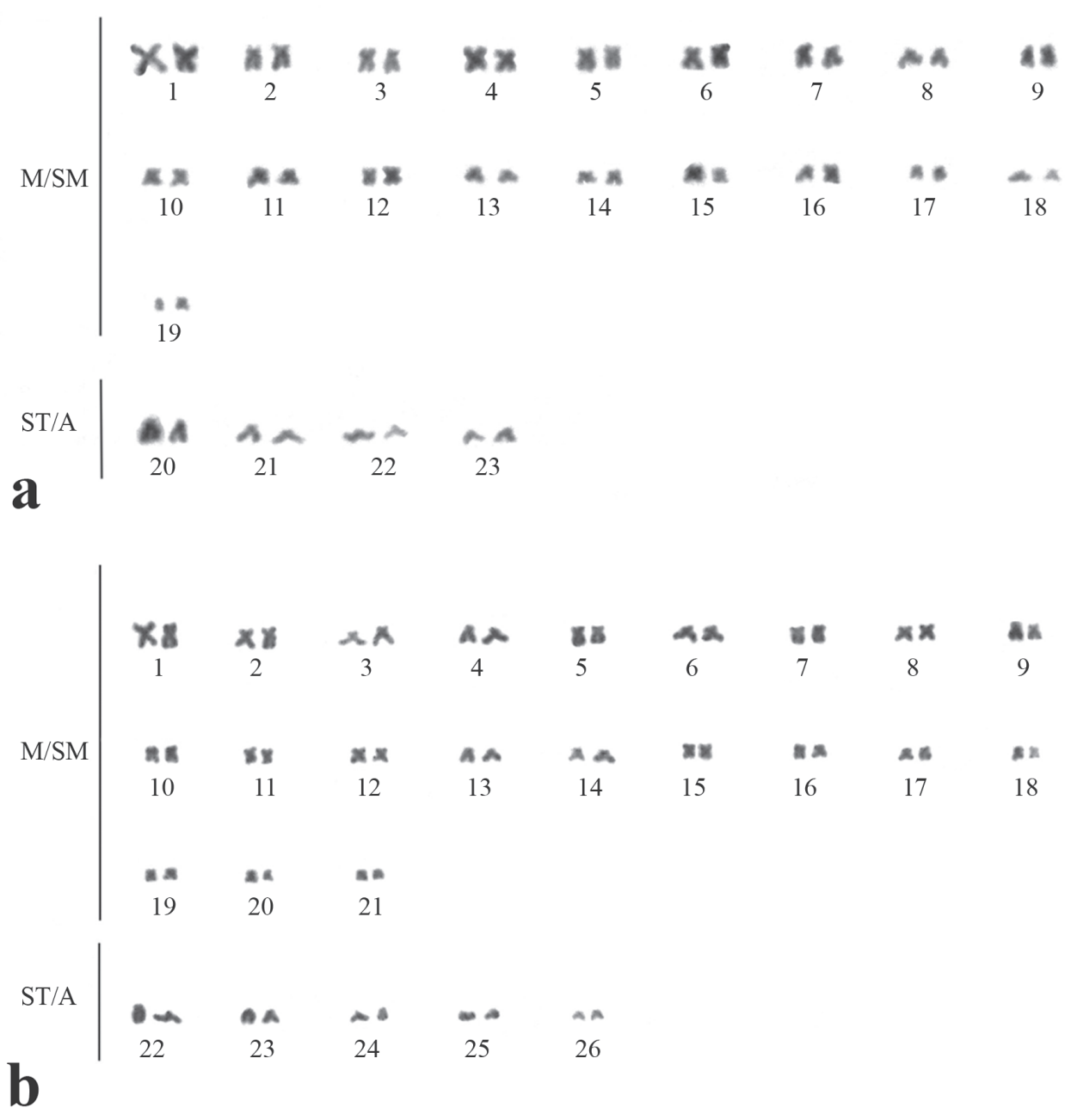

Fig. 2. Karyotypes of Pimelodella from the Miranda River, Passo do Lontra, Mato Grosso do Sul State. (a) $2 n=46$, and (b) $2 n=52$. 


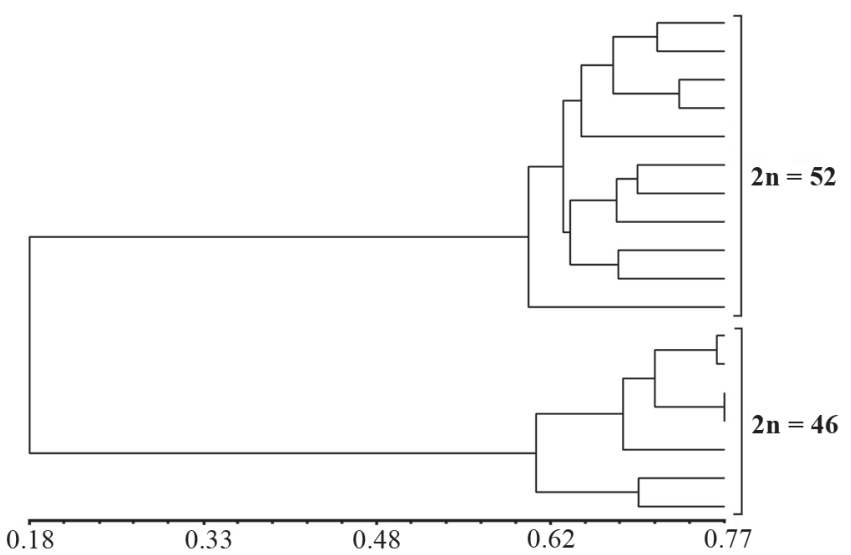

Fig. 3. Dendrogram of genetic similarity among the species of Pimelodella from the Miranda River based on the Jaccard coefficient and on UPGMA clustering method, showing the formation of two clusters.

Morphometry. The two species could also be differentiated by multivariate analysis of the Principal Components. The first axis, representing the size factor, retained $90.6 \%$ of the morphometric measurement variance; the second and third axes, which represent the shape, retained $3.0 \%$ and $2.2 \%$, respectively (Table 1). The first axis revealed that most specimens with $2 \mathrm{n}=52$ chromosomes, which are distributed to the right in Fig. 4, were larger than those with $2 n=46$. The

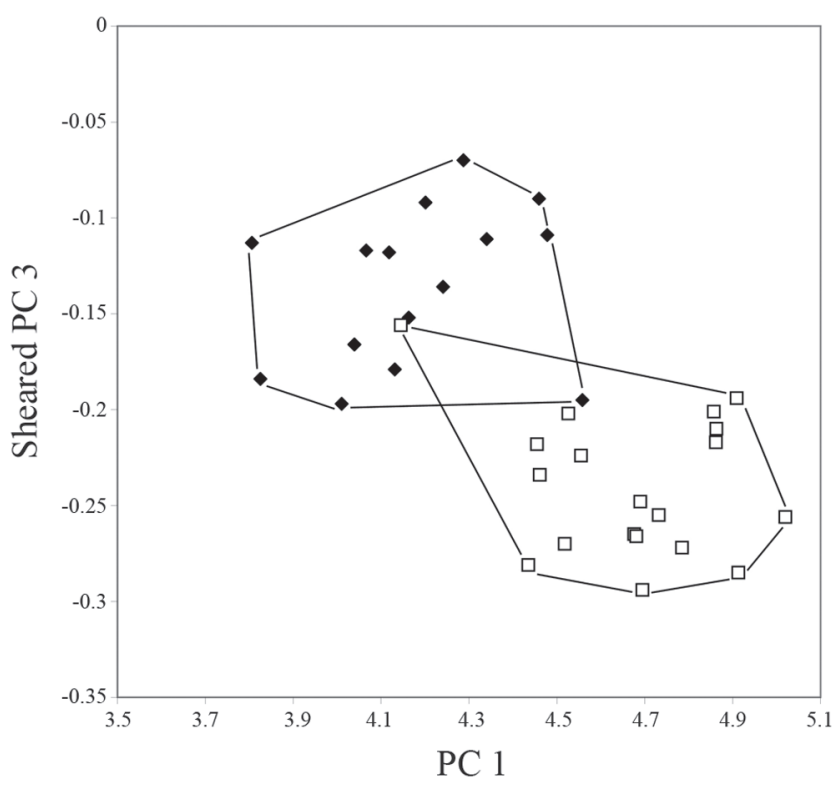

Fig. 4. Projection of the individual scores obtained through the analysis of the Principal Components of the combined samples of Pimelodella with $2 \mathrm{n}=46$ (diamonds) and with $2 \mathrm{n}=52$ (squares).
Table 1. Weight of variables, eigenvalues and percentages relating to the first, second, and third eigenvectors of the Principal Components obtained from the analysis of combined samples of Pimelodella species.

\begin{tabular}{lccc}
\hline & CP 1 & CP 2 & CP3 \\
\hline 1. Standard length & 0.289726 & 0.015837 & -0.044266 \\
2. Head length & 0.258083 & 0.077697 & -0.156947 \\
3. Snout length & 0.276907 & 0.069637 & 0.007304 \\
4. Eye diameter & 0.171324 & 0.217980 & 0.342959 \\
5. Pre-dorsal length & 0.245775 & 0.200042 & 0.188072 \\
6. Dorsal-fin base length & 0.314548 & -0.316442 & -0.418420 \\
7. Adipose-fin base length & 0.398125 & 0.026110 & -0.275871 \\
8. Dorsal-fin spine length & 0.242476 & 0.365517 & 0.120618 \\
9. Caudal peduncle depth & 0.241554 & -0.223113 & 0.034162 \\
10. Pre-ventral length & 0.283770 & 0.009382 & -0.111584 \\
11. Anal-fin base length & 0.230008 & -0.719201 & 0.518514 \\
12. Pectoral-fin spine length & 0.289681 & 0.308775 & 0.272182 \\
13. Interorbital width & 0.301805 & -0.066202 & -0.458721 \\
\hline Eigenvalue & 0.108 & 0.004 & 0.003 \\
Relative porcentages & 90.6 & 3.0 & 2.2 \\
Acumulated relative porcentages & 90.6 & 93.6 & 95.8 \\
\hline
\end{tabular}

differentiation of the species can be observed on the third axis, however with a small morphological overlap between the two species. The smallest specimen with $2 \mathrm{n}=52$ chromosomes was morphometrically similar to the individuals with $2 n=46$ chromosomes. Moreover, the largest specimen with $2 n=46$ chromosomes showed greater similarity to the group with $2 n=52$. Thus, there is evidence of the need for caution when identifying specimens of these extreme sizes with the morphometric characters. Although there was a small overlap between the two species, the specimens of each remained relatively cohesive, indicating that they are really distinct.

The variables with the highest weight for the group with $2 n=46$, indicated by positive values in the third eigenvector, were: eye diameter, length of anal fin base, and length of pectoral spine. For the group with $2 n=52$, the variables with higher weight were: length of dorsal fin base, length of adipose fin base, and interorbital distance, which were negative in the third eigenvector (Table 1).

The body proportion analysis (Table 2) revealed that the limits of variation of all variables overlap between the two species, but with significant differences between some means. Thus, although there is an overlap in the variation ranges, there is a shift of values in relation to the mean values, which significantly differentiate the two species from each other (according to the $t$ Student test). Many variables with such differences coincide with those that were highly noticeable in the third axis of the Principal Component analysis as having the highest weights in the discrimination of the two species. In species with $2 n=46$, the coinciding variable was the length of the anal fin base, and in species with $2 n=52$, the length of the dorsal fin base, the length of adipose fin base, and the interorbital distance. In the analysis of means, the highest values of the pre-dorsal distance, caudal peduncle height, 
Table 2. Morphometry of Pimelodella with $2 \mathrm{n}=46$ (13 specimens) and Pimelodella with $2 \mathrm{n}=52$ (19 specimens. Except barbel with 18 specimens) from the Miranda River Basin, Pantanal, MS. SD = Standard deviation; * = Means significantly different.

\begin{tabular}{lccccc}
\hline & \multicolumn{2}{c}{$2 \mathrm{n}=46(13$ ex. } & \multicolumn{2}{c}{$2 \mathrm{n}=52(19$ ex. $)$} & $t$ test $(\mathrm{p})$ \\
\hline & $\begin{array}{l}\text { minimum- } \\
\text { maximum }\end{array}$ & mean \pm SD & $\begin{array}{c}\text { minimum- } \\
\text { maximum }\end{array}$ & mean $\pm \mathrm{SD}$ & \\
\hline Standard length $(\mathrm{mm})$ & $60.7-93.2$ & $76.3 \pm 9.561$ & $89.5-156.7$ & $111.1 \pm 16.478$ & $<0.0001^{*}$ \\
& \multicolumn{2}{c}{ Percentages of standard length } \\
Head length & $21.6-24.3$ & $23.0 \pm 0.717$ & $20.4-24.6$ & $22.4 \pm 0.998$ & 0.0729 \\
Pre-dorsal length & $28.2-33.4$ & $30.1 \pm 1.572$ & $25.8-31.7$ & $27.7 \pm 1.406$ & $0.001153^{*}$ \\
Dorsal-fin base length & $14.4-19.2$ & $16.8 \pm 1.649$ & $15.9-19.4$ & $18.0 \pm 0.993$ & $0.0163^{*}$ \\
Adipose-fin base length & $31.2-39.9$ & $35.5 \pm 2.296$ & $36.9-44.2$ & $41.5 \pm 1.873$ & $<0.0001^{*}$ \\
Dorsal-fin spine length & $18.3-24.4$ & $20.1 \pm 1.530$ & $14.8-22.1$ & $18.8 \pm 2.070$ & 0.0619 \\
Caudal peduncle depth & $7.0-9.0$ & $8.0 \pm 0.589$ & $6.2-8.2$ & $7.3 \pm 0.447$ & $0.0011^{*}$ \\
Pre-ventral length & $40.0-44.9$ & $43.5 \pm 1.442$ & $41.6-45.2$ & $43.3 \pm 0.886$ & 0.6232 \\
Anal-fin base length & $10.5-16.8$ & $12.3 \pm 1.709$ & $8.5-11.9$ & $10.7 \pm 0.967$ & $0.0016^{*}$ \\
Pectoral-fin spine length & $16.9-20.3$ & $18.6 \pm 1.049$ & $15.4-19.8$ & $18.0 \pm 1.16$ & 0.1122 \\
Maxillary barbel length & $63.6-96.8$ & $81.9 \pm 8.666$ & $54.5-81.5$ & $70.8 \pm 7.206$ & $0.0031^{*}$ \\
& \multicolumn{2}{c}{ Percentages of head length } & \\
Snout length & $64.1-70.4$ & $67.1 \pm 2.184$ & $63.1-72.2$ & $66.9 \pm 2.528$ & 0,81396 \\
Eye diameter & $23.8-31.4$ & $26.4 \pm 1.966$ & $20.3-23.9$ & $21.9 \pm 1.034$ & $<0.0001^{*}$ \\
Interorbital width & $21.5-29.0$ & $25.6 \pm 2.018$ & $23.9-31.7$ & $27.8 \pm 2.303$ & $0.0081^{*}$ \\
\hline
\end{tabular}

eye diameter, and length of maxillary barbel stood out in species with $2 n=46$, except for the length of the pectoral-fin spine. The latter should therefore be used with caution.

Spines. The spines in the two species were very similar with regard to the saw-tooth pattern in the anterior and posterior margins of (Fig. 5) and cannot be used as a distinguishing feature between them. In both species, the anterior margin is fully serrated with wide retrorse serrations covering approximately 25 to $33 \%$ of the pointy end of the spine; heading toward the base of the spine, there are small orthogonal sawtoothed margins. The posterior margin presents larger retrorse and more robust serrations than the anterior margin with ossified saws covering 70 to $75 \%$ of the length.

Filament on the dorsal fin and caudal fin lobes. Contrary to what was initially assumed, the dorsal fin filament does not differentiate among the two species, as both possess this same feature (Fig. 6). However, it was possible to correlate their presence with sex (Table 3): males usually do present the dorsal fin filament, but females do not. The length of this filament is apparently not related to the increase in size of the

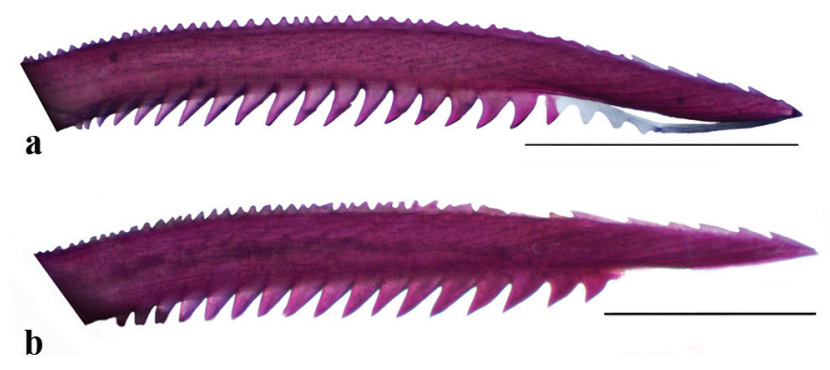

Fig. 5. Pectoral-fin spines in Pimelodella from the Miranda River. a) $2 \mathrm{n}=46$; b) $2 \mathrm{n}=52$. Scale bar $=5 \mathrm{~mm}$. specimen, since the two smaller males $(\mathrm{SL}=107.4 \mathrm{~mm}$ and $108.1 \mathrm{~mm}$ ) had the filament, while one of the largest (SL = $117.6 \mathrm{~mm}$ ) did not bear the filament. The Pearson correlation coefficient between the length of the filament and the standard length in males of Pimelodella $2 \mathrm{n}=52$, corroborates this hypothesis, as it showed a very low value $\left(\mathrm{r}^{2}=0.06, \mathrm{~N}=7\right)$.

The Pearson correlation coefficient demonstrates that the increase in standard length explains about $40 \%$ of the variation in length of the upper lobe caudal fin in Pimelodella $2 \mathrm{n}=52$, whereas in Pimelodella $2 \mathrm{n}=46$, this explanation comprised approximately $57 \%$ of that variation (Fig. 7). As occurred in the multivariate morphometric analysis, the smaller specimens of Pimelodella $2 \mathrm{n}=52$ tend to be confounded with the larger specimens of Pimelodella $2 \mathrm{n}=46$. Nevertheless, the calculation of the allometric coefficient reveals that in Pimelodella $2 \mathrm{n}=52$, the upper lobe of the caudal fin in males shows positive allometric growth $(\mathrm{b}=$ 1.11), whereas in Pimelodella $2 \mathrm{n}=46$, the allometric growth is negative $(b=0.61)$, meaning that as the standard length increases in the former species, the upper lobe of the caudal fin grows in the same proportion, while the opposite occurs with the second species.

\section{Discussion}

The hypothesis that the sample could contain four sympatric species of Pimelodella from the Miranda River was not confirmed by the analyses accomplished in this study. The features initially observed, such as the presence of elongated filament on the dorsal fin and the morphologic characters of the caudal fin lobes, as traditionally used, can be variable between and within species.

Hence, this study evidenced a case of morphological convergence in species with a high level of molecular and cytogenetic diversification. The existence of morphological similarities between related but different organisms is evidence 
for evolution by natural selection. Thus, it is possible that environmental pressures are selecting similar body forms among different species, favoring both. Two or more species identified as one fall within the concept of cryptic species. In Pimelodella, some sympatric species are morphologically very similar and probably constitute a species complex, hampering their identification. According to Eigenmann (1917), "As the color and the size of the eye also vary with age and with locality, and, as all of these characters vary independently, the defining of species of Pimelodella becomes a delicate and difficult task." This difficulty was also observed by Martin \& Bermingham (2000), while studying Pimelodella chagresi (Steindachner, 1876) from Central America. They utilized morphology, RFLP, and mitochondrial genes as tools to unravel the problem.

In a review on cytogenetic studies of the family Heptapteridae carried out by Swarça et al. (2007) it was found that the diploid number of $2 \mathrm{n}=52$ has already been observed in the genus Pimelodella in P. gracilis, from the Paraguay River, Mato Grosso do Sul State; Pimelodella sp., from the Paraná River, Paraná State; P. cristata (Müller \& Troschel, 1849), from the Araguaí River, Mato Grosso State; and $P$. aff. avanhandavae Eigenmann, 1917, from the Tibagi River, Paraná State. However, among all above-cited species, only $P$. gracilis occurs in the Paraguay River basin (Britski et al., 2007), but the morphological characteristics of individuals that had $2 \mathrm{n}=52$ did not coincide with the characters used to identify $P$. gracilis, because some presented the first dorsal fin ray prolonged as a filament. According to Miranda-Ribeiro (1914) and Britski et al. (2007), this is a feature found in P. taenioptera, a name that can be applied to the species with $2 \mathrm{n}=52$ chromosomes, as they share many morphological characteristics, except for the color pattern. However, as noted by Eigenmann (1917), this character is subject to a great variation.

The diploid number of $2 n=46$ is shared by several species of Pimelodella, among which are: P. avanhandavae (Vissotto et al., 1999), P. aff. avanhandavae (Swarça et al., 2003), P. boschmai van der Stigchel, 1964 (Garcia \& AlmeidaToledo, 2010), Pimelodella sp. (Vasconcelos \& MartinsSantos, 2004; Garcia et al., 2010), P. meeki Eigenmann, 1910 (Vidotto et al., 2004; Garcia \& Almeida-Toledo, 2010; Borba et al., 2011), indicating that this number is the most commonly observed in this genus. Nevertheless, this is currently the first publication reporting the occurrence of that diploid number in a species of Pimelodella from the Pantanal. The other species that have the dorsal fin filament elongated is $P$. griffini, which differs from P. taenioptera owing to the shortest length of the adipose fin base (Britski et al., 2007), as observed for the species with $2 \mathrm{n}=46$. As stated by Eigenmann (1917), P. griffini has barbels reaching the tip of the pelvic fin or are slightly shorter, whereas in specimens with $2 n=46$, the barbel is extremely elongated. Eigenmann (1917) also observed that "The length of the barbels in the same species differs with age. In the young, the barbels are relatively short. They grow disproportionately larger with the growth of the fish and then lag behind again in their increase in length. The length of the barbels of the same
Table 3. Frequency of Pimelodella individuals with or without dorsal fin filament in relation to the diploid number and gender $(\mathrm{M}=$ male; $\mathrm{F}=$ female $)$.

\begin{tabular}{lccccc}
\hline & \multicolumn{2}{c}{ With filament } & \multicolumn{2}{c}{ Without filament } & \\
\cline { 2 - 5 } & $\mathrm{M}$ & $\mathrm{F}$ & $\mathrm{M}$ & $\mathrm{F}$ & Total \\
\hline $2 \mathrm{n}=46$ & 1 & 0 & 0 & 3 & 4 \\
$2 \mathrm{n}=52$ & 7 & 0 & 1 & 1 & 9 \\
\hline Total & 6 & 0 & 1 & 4 & 13 \\
\hline
\end{tabular}

species not only differs with age, but sometimes also with locality".

In freshwater fish, several cryptic species have been detected using cytogenetics. This tool allowed the observation of intraspecific chromosomal variations, enabling the identification of species complexes, as observed in Eigenmannia sp. (Almeida-Toledo et al., 2002), Astyanax fasciatus (Cuvier, 1819) (Pazza et al., 2008) and Hoplias malabaricus (Bloch, 1794) (Rosa et al., 2009).

The differences between $P$. griffini and $P$. taenioptera were also corroborated by the molecular analysis with the formation of two distinct clusters corresponding to the karyotypes found. Individuals of these clusters also showed different degrees of intraspecific genetic similarity, evidencing the variability in each species, which was observed in the morphological characteristics.

According to Chambers et al. (1998), the RAPD analysis is a method that has good potential for the differentiation of closely related species. The same was ascertained by Almeida et al. (2003) in a comparative study of six species, which comprised four species of Siluriformes, two of them were Pimelodella, whereby they observed that individuals of each species remained clustered.

Morphology also proved useful in the separation of the two species. The morphometric analysis is extensively used in descriptions of species for being informative and for the ease of obtaining. The multivariate morphometric analysis was important to observe the separation of the species by morphometric characters, as well as to indicate which of these characters had the greatest weight in the separation. However, as this is an exploratory method, it was not possible to know the magnitude of change in these variables. This matter was solved with body proportion calculations.

Another character relevant to the systematics of Pimelodella considered by Eigenmann (1917) is the pectoral fin spine and its saws. This author presented 44 illustrations of spines in different species, where one can observe the similarity in the form of the thorns among the species analyzed in this work and Pimelodella hasemani Eigenmann 1917, which occurs from the Guaporé to the Madeira River basins, and also in the Amazon basin. The occurrence of this species in the Paraguay River basin has not yet been reported, but it is possible that it may also occur in that basin due to the proximity of its headwaters. However, as stated by Eigenmann (1917), P. hasemanni does not possess the elongated filament on the dorsal fin and the caudal fin 


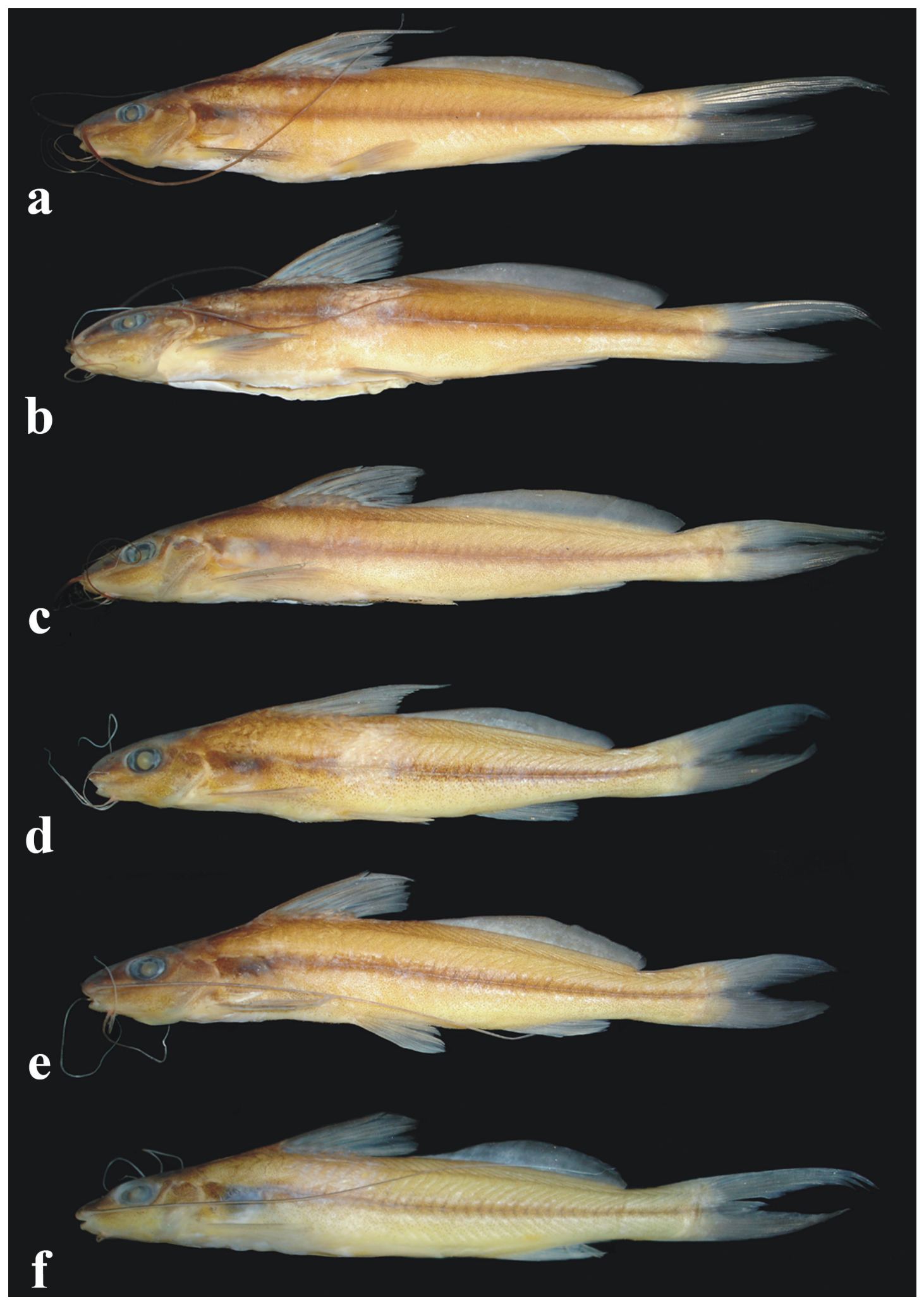

Fig. 6. a to c) Pimelodella $2 \mathrm{n}=52$, from the Miranda River basin, Passo do Lontra, MS: a) dorsal filament and upper lobe of caudal fin elongated (male, $123.6 \mathrm{~mm} \mathrm{SL}$ ), b) dorsal fin filament slightly elongated and upper lobe of caudal fin elongated (male, $106.8 \mathrm{~mm}$ $\mathrm{SL}$ ), c) filament on dorsal fin absent and upper lobe of caudal fin not elongated (male, $117.6 \mathrm{~mm} \mathrm{SL}$ ). d to f) Pimelodella $2 \mathrm{n}=46$ from the Miranda River basin, Passo do Lontra, MS: d) filament on dorsal fin elongated and upper lobe of caudal fin slightly elongated (male, $82.7 \mathrm{~mm} \mathrm{SL}$ ), e) Filament on the dorsal fin slightly elongated and upper lobe of caudal fin not elongated (female, 93.2 mm SL), f) Filament on the dorsal fin absent and upper lobe of caudal fin elongated (female, $85.1 \mathrm{~mm} \mathrm{SL}$ ). 


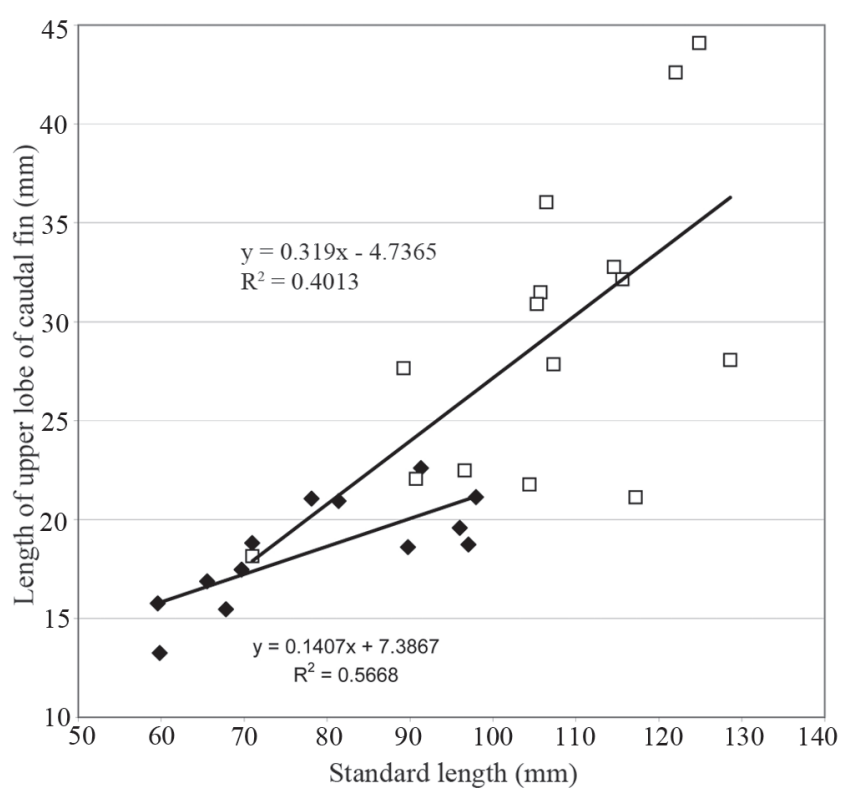

Fig. 7. Relationship between the standard length and the length of the upper lobe of the caudal fin in Pimelodella $2 \mathrm{n}=$ 46 (dark diamonds, $\mathrm{N}=13$ ) and $2 \mathrm{n}=52$ (light squares, $\mathrm{N}=15$ ).

lobes are about the same size. However, the characteristics of the thorn in this species with $2 \mathrm{n}=46$ does not permit its identification as $P$. griffini, because this species does not present strong saws on the posterior margin and the small saws on the anterior margin are slightly conspicuous. Despite the emphasis given by Eigenmann (1917) to the pectoral spine, he noted that: "The pectoral spines also vary somewhat with growth. With age the thorns increase in number by the addition of new ones toward the tip and come to occupy a larger portion of the length of the spine."

Among the other species observed in the Pantanal (Britski et al., 2007), P. notomelas Eigenmann 1917 differs from $P$. griffini and $P$. taenioptera for having a black wedge-shaped spot on the dorsal fin and for not presenting a dark lateral stripe along the lateral line. Pimelodella mucosa Eigenmann $\&$ Ward is also easily identified by the pore sizes of the lateral line in the lower region of the head, starting between the edges of the operculum and extending toward the mandible with a diameter approximately equal to the diameter of the pupil. Pimelodella gracilis and P. megalura, in turn, may be distinguished from $P$. griffini and P. taenioptera by the absence of the dorsal fin filament. However, it is possible that a considerable number of identifications of females of these two species have been incorrectly made. In this case, it is essential to identify their gender and age, since young females can cause confusion. As taxonomy is primarily based on morphological characteristics, it has often occurred that morphologically indistinguishable organisms have been identified as belonging to the same species, when, in fact, they are distinct species. Pimelodella griffini and $P$. taenioptera show morphological characteristics which, in principle, can cause confusion between them. However, the joint analysis of the karyotype, molecular biology and morphometry allowed distinguishing them safely.

Thus, only the employment of various analytical techniques enabled an accurate detection of these apparently cryptic taxonomic units. The non-recognition of species has several consequences that range from the underestimation of the real biodiversity of each site to the threat of extinction of rare species that can be confused with other more common species (Frankham et al., 2008). Also, it is worth emphasizing the importance of the identification of these sympatric, cryptic species, to ensure that estimates of fish diversity in the Pantanal are accurately made.

\section{Acknowledgments}

The authors thank the Centro Universitário Filadélfia, the Universidade Estadual de Londrina, and the Universidade Federal do Mato Grosso do Sul for their logistic support. OAS is a productivity research fellow of CNPq (proc. 308624/2009-2).

\section{Literature Cited}

Almeida, S. F., L. M. K. Sodré \& E. P. B. Contel. 2003. Population structure analysis of Pimelodus maculatus (Pisces, Siluriformes) from Tietê and Paranapanema rivers (Brazil). Genetics and Molecular Biology, 26: 301-305.

Almeida-Toledo, L. F., M. F. Z. Daniel-Silva, C. B. Moysés, S. B. A. Fonteles, C. E. Lopes, A. Akama \& F. Foresti. 2002. Chromosome evolution in fish: Sex chromosome variability in Eigenmannia virescens (Gymnotiformes, Sternopygidae). Cytogenetics and Genome Research, 99: 164-169.

Bertollo, L. A. C., C. S. Takahashi \& O. Moreira-Filho. 1978. Cytotaxonomic considerations on Hoplias lacerdae (Pisces, Erythrinidae). Brazilian Journal of Genetics, 2: 17-37.

Bockmann, F. A. \& G. M. Guazzelli. 2003. Family Heptapteridae (Heptapterids). Pp. 406-431. In: Reis, R. E., S. O. Kullander \& C. J. Ferraris, Jr. (Eds.). Check List of the Freshwater Fishes of South and Central America. Porto Alegre, Edipucrs, 729p.

Bookstein, F. L., B. Chernoff, R. L. Elder, J. M. Humphries-Jr., G. R. Smith \& R. E. Strauss. 1985. Morphometrics in Evolutionary Biology: The geometry of size and shape change, with examples from fishes. Special Publication 15, The Academy of Natural Sciences of Philadelphia, 277p.

Borba, R. S., E. L. Silva, A. C. S. Pacheco, P. P. Parise-Maltempi \& A. L. Alves. 2011. Trends in the karyotypic evolution of the Neotropical catfish Family Heptapteridae Bockmann, 1998 (Teleostei: Siluriformes). Reviews in Fish Biology and Fisheries, 22: 509-518.

Britski, H. A., K. Z. S. Silimon \& B. S. Lopes. 2007. Peixes do Pantanal. Manual de identificação. Brasília: Embrapa-SPI; Corumbá: Embrapa CPAP, 2ed., 227p.

Chambers, R. J., C. D. McQuaid \& R. Kirby. 1998. The use of randomly amplied polymorphic DNA to analyse the genetic diversity, the systematic relationships and the evolution of intertidal limpets, Siphonaria spp. (Pulmonata: Gastropoda), with different reproductive modes. Journal of Experimental Marine Biology and Ecology, 227: 49-66. 
Coelho, A. S. G. 2001. Software: Dboot - Avaliação de dendrogramas baseados em estimativas de distâncias/similaridades genéticas através do procedimento de bootstrap Versão 3.0. Departamento de Biologia Geral, Instituto de Ciências Biológicas, Universidade Federal de Goias, Goiânia, GO.

Dingerkus, G. \& L. D. Uhler. 1977. Enzyme clearing of alcian blue stained whole small vertebrates for demonstration of cartilage. Stain Technology Journal, 52: 229-232.

Eigenmann, C. H. 1917. Pimelodella and Typhlobagrus. Memoirs of the Carnegie Museum, 7: 229-258.

Frankham, R., J. D. Ballou \& D. A. Briscoe. 2008. Fundamentos da genética da conservação. Ribeirão Preto: Editora SBG.

Garcia, C. \& L. F. Almeida-Toledo. 2010. Comparative chromosomal analyses in species of the genus Pimelodella (Siluriformes, Heptapteridae): occurrence of structural and numerical polymorphisms. Caryologia, 63: 32-40.

Hammer, O., D. A. T. Harper \& P. D. Ryan. 2001. PAST: Palaentological Statistics Software Package for education and data analysis. Palaeontologia Electronica, 4: 1-9.

Levan, A., K. Fredga \& A. A. Sandberg. 1964. Nomenclature for centromeric position on chromosomes. Hereditas, 52: 201-220.

Martin, A. P. \& E. Bermingham. 2000. Regional endemism and cryptic species revealed by molecular and morphological analysis of a widespread species of Neotropical catfish. Proceedings of the Royal Society of London, Biological Sciences, 267: 11351141.

Mcleod, N. 1990. Shear. In: Rohlf, F. L. \& F. L. Bookstein (Eds.). Proceedings of Michigan Morphometrics Workshop. University of Michigan, Museum of Zoology, 380p.

Miranda-Ribeiro, A. 1914. Historia Natural: Zoologia: Pimelodidae, Trachycorystidae, Cetopsidae, Bunocephalidae, Auchenipteridae, e Hypophthalmidae. Comissão de Linhas Telegraphicas Estratégicas de Matto-Grosso ao Amazonas, Anexo 5, 3-15p.

Neff, N. A. \& L. F. Marcus. 1981. A survey of multivariate methods for Systematics. American Museum of Natural History, New York, 235p.

Pazza, R., S. A. F. Kavalco, P. R. Penteado, K. F. Kavalco \& L. F. Almeida-Toledo. 2008. The species complex Astyanax fasciatus Cuvier, 1819 (Teleostei, Characiformes): A multidisciplinary approach. Journal of Fish Biology, 72: 2002-2010.
Reis, R. E., S. O. Kullander \& C. J. Ferraris Jr. 2003 (Eds.). Check list of the freshwater fishes of South and Central America. EDIPUCRS, Porto Alegre.

Rohlf, F. J. 2000. Numerical Taxonomy and Multivariate Analysis System. NTSYS-PC. Version 2.10. Setauket, New York, Exeter Software.

Rosa, R., M. Caetano-Filho, O. A. Shibatta \& L. Guiliano-Caetano. 2009. Cytotaxonomy in distinct populations of Hoplias aff. malabaricus (Characiformes, Erythrinidae) from lower Paranapanema River basin. Journal of Fish Biology, 75: 26822694.

Shibatta, O. A. 1998. Sistemática e evolução da família Pseudopimelodidae (Ostariophysi, Siluriformes), com a revisão taxonômica do gênero Pseudopimelodus. Unpublished Ph.D. Dissertation, Universidade Federal de São Carlos, São Paulo, $357 \mathrm{p}$.

Souza, L., A. C. Swarça \& A. L. Dias. 2004. Analyses of the nucleolus organizer region in 5 species of the genus Pimelodus (Siluriformes, Pimelodidae) using $\mathrm{AgNO}_{3}$ and FISH with the 18S rDNA probe. Caryologia, 57: 145-151.

Swarça, A. C., A. P. Vidotto \& A. L. Dias. 2003. Cytogenetic characterization of Pimelodella aff. avanhandavae (Siluriformes, Pimelodidae) from Tibagi River (Paraná State, Brazil). Caryologia, 56: 421-425.

Swarça, A. C., A. S. Fenocchio \& A. L. Dias. 2007. An update cytogenetic review for species of the families Pseudopimelodidae, Pimelodidae and Heptapteridae (Pisces, Siluriformes). Suggestion of a cytotaxonomical classification. Caryologia, 60: 338-348.

Vasconcelos, C. \& I. A. Martins-Santos. 2004. Chromosome polymorphism in species of Pimelodidae family (Pisces, Siluriformes). Hereditas, 132: 103-109.

Vidotto, A. P., A. C. Swarça, A. S. Fenocchio \& A. L. Dias. 2004. Cytogenetics studies in three Pimelodella meeki populations (Pisces, Pimelodidae) from Tibagi River basin (Brazil). Journal of Heredity, 95: 517-520.

Submitted September 13, 2012 Accepted by October 25, 2012 by Claudio Oliveira Published March 31, 2013 